\title{
LA MÚSICA EN LA PUBLICIDAD QUE ATRAE A LOS JÓVENES
}

\section{Music in Advertising that Attracts Undergraduates}

\section{A música na publicidade que atrai aos jovens}

\author{
Juana Rubio-Romero, Universidad Antonio de Nebrija (España) \\ jrubio@nebrija.es
}

Marta Perlado-Lamo de Espinosa, Universidad Antonio de Nebrija (España)

mperlado@nebrija.es

Mar Ramos-Rodríguez, Universidad Antonio de Nebrija (España)

mramos@nebrija.es

Recibido: 14 de febrero de 2018

Aprobado: 01 de julio de 2018

\section{RESUMEN}

Estudio de las claves de éxito de la música en la publicidad audiovisual que más gusta a los jóvenes universitarios. La investigación se basa en los resultados de un estudio longitudinal que se lleva a cabo en el festival publicitario Jóvenes Tocados por la Publicidad, con distintas categorías de premios. En el artículo se analizan los anuncios nominados y ganadores a la categoría de música-sonido de las últimas diez ediciones (2005-2016) del festival, en total 30 anuncios. Para seleccionar los spots que alcanzan mayor notoriedad entre los jóvenes universitarios y entender el porqué de su selección, se utiliza una metodología triangular, que aplica métodos cuantitativos y cualitativos. Los resultados del estudio confirman el valor y la trascendencia de la música en el éxito de la publicidad audiovisual que más atrae a los jóvenes, observando que existe poca relevancia de la clasificación música 


\section{DISERTACIONES}

ESTUDIOS

El papel del sonido en la comunicación: contribución, funciones y efectos

ISSN: $1856-9536$

Doi: http://dx.doi.org/10.12804/revistas.urosario.edu.co/disertaciones/a.6537

Volumen 12, Número 2 / Julio-diciembre 2019

Versión PDF para imprimir desde

http://revistas.urosario.edu.co/index.php/disertaciones

original-preexistente en los anuncios escogidos y una mayor incidencia de la categoría diegética-extradiegética. Se evidencia que lo que más valoran los jóvenes en la música de la publicidad es lo que les hace sentir, prefiriendo canciones emotivas, sensibles y con cierta profundidad. Además, este target aprecia que la música en la publicidad sea coherente y adaptada al mensaje de la campaña.

Palabras clave: música, publicidad, jóvenes, televisión, internet.

\section{ABSTRACT}

This study analyses some essential aspects of the music used in the audiovisual advertising most liked by university students. The results of a longitudinal study carried out at the Jóvenes Tocados por la Publicidad ('Undergraduates Touched by Advertising') festival are the base of this research, which has several different prize categories. We analyzed the nominated and winning advertisements from the last ten editions (2005-2016) of this festival in the 'music and sound' category, representing a total of thirty. To select the spots that achieved the best notoriety among the university students surveyed and to understand the reasons for this preference, we used a triangular methodology that applied both quantitative and qualitative methods. Our results confirm the value and transcendence of music in the production of audiovisual advertising that successfully attracts undergraduates; moreover, we observed that the originality or pre-existence of the music had little effect on their preference for the spots, but that the use of diegetic or extradiegetic music did affect its likelihood of being chosen. There was evidence that undergraduates most value music in advertising that causes them to have an emotional response, and that they prefer emotive and sensitive songs that bring some sense of depth. This target audience most appreciates music in advertising that is consistent with and adapted to the campaign's message.

Keywords: Music, advertising, undergraduates, television, internet.

\section{RESUMO}

Estudo das chaves do sucesso da música na publicidade audiovisual que mais gosta aos jovens universitários. A pesquisa baseia-se nos resultados de um estudo longitudinal que se leva a cabo no festival publicitário Jóvenes Tocados por la Publicidad, com diferentes categorias de prémios. No artigo analisam-se os anúncios nominados e ganhadores à categoria de música/som das últimas dez edições (2005-2016) do festival, em total trinta anúncios. Para selecionar os spots que alcançam maior notoriedade entre os jovens universitários e entender o porquê de sua eleição, utiliza-se uma metodologia triangular, que aplica métodos quantitativos e qualitativos. Os resultados do estudo confirmam o valor e a transcendência da música no sucesso da publicidade audiovisual que mais atrai aos jovens, observando que existe pouca relevância da classificação música original/pré-existente nos anúncios escolhidos e uma maior incidência da categoria diegética/extradiegética. Evidencia-se que o que mais valoram os jovens na música da publicidade é o lhes faz sentir, preferindo músicas emotivas, sensíveis e com certa profundidade. Além disso, este target aprecia que a música na publicidade seja coerente e adaptada à mensagem da campanha.

Palavras-chave: música, publicidade, jovens, televisão, internet. 


\section{DISERTACIONES}

ESTUDIOS

\section{Introducción}

Desde los inicios de la publicidad audiovisual, la música ha sido un componente de éxito por su aportación al impacto y a la notoriedad del mensaje, logrando mayor eficacia en la difusión, la acogida y la memorización de los anuncios.

La música aumenta y facilita el recuerdo en los mensajes publicitarios, potencia sentimientos y emociones, y conecta con diferentes públicos objetivos. "Es probablemente uno de los caminos publicitarios más completos, participativos y eficaces que existen [...] sirve para comunicar cosas que no se pueden comunicar mejor de otra manera: una sensación, un estilo, una clase, un estado de ánimo" (Bassat, 1993, p. 107). La música contribuye, pues, a la eficacia de la publicidad porque la hace más atractiva y colabora a dar sentido al anuncio, le ofrece continuidad y estimula el recuerdo (Palencia-Lefler, 2009).

Los jingles ${ }^{1}$ o canciones publicitarias son precisamente uno de los formatos más eficaces para potenciar la memoria del mensaje en los consumidores. Estos recuerdan las melodías y letras de los anuncios, aunque haga tiempo que ya no se emitan (Bassat, 1993; Guijarro \& Muela, 2003; Palencia-Lefler, 2009).

En los comienzos de la televisión, se recurrió a melodías de fácil recuerdo para asociarlas al producto (Gómez Rodríguez, 2005; Barsa \& Montañés, 2006), y ya en las décadas de los ochenta y noventa, las canciones publicitarias estuvieron menos ligadas al producto y más vinculadas al aspecto emocional.

La música es un factor para lograr impacto sobre el espectador ganando terreno a la narrativa, más propia de los spots del siglo XX (Fraile, 2012). En un anuncio, la melodía aporta atributos que entran a formar parte de la estructura discursiva. Si la música da significado a las imágenes, estas dan significado a la música; existe una interacción entre los dos medios (Sedeño, 2006).

A pesar de su importancia y notoriedad en la publicidad, en la sociedad digital se trata de un elemento ausente en buscadores y poco utilizado en los medios de origen gráfico (diarios y revistas online). Sin embargo, en YouTube es una de las piezas principales, así como en canales musicales, como Spotify o Apple Music.

La aparición de la música en la publicidad ha sido fundamental para el crecimiento del video, formato en el que es protagonista. El videoclip está logrando cada vez mayor visibilidad y efectividad gracias a internet. Precisamente, una de las campañas de publicidad más efectivas de los últimos años corresponde a mTv España, con la famosa canción Amo a Laura, del grupo Happiness, compuesta para la campaña (Sánchez Olmos, 2009) y que se emitió únicamente por la red.

El carácter subjetivo de la música es una clave para entender el mundo de las emociones y escapar del de la razón, y es esta afirmación la que une la música con la publicidad, porque intenta persuadir y llevar al espectador a un territorio más relacionado con lo aspiracional (Fernández Gómez, 2002; Sánchez-Porras, 2013).

1 Palencia-Lefler (2009) diferencia entre jingle-marca y jingle-adsong; el primero, el mensaje publicitario hecho canción; el segundo transmite los valores que envuelven al producto o a la marca. 


\section{DISERTACIONES}

ESTUDIOS

El papel del sonido en la comunicación: contribución, funciones y efectos

ISSN: $1856-9536$

Doi: http://dx.doi.org/10.12804/revistas.urosario.edu.co/disertaciones/a.6537

Volumen 12, Número 2 / Julio-diciembre 2019

Versión PDF para imprimir desde

http://revistas.urosario.edu.co/index.php/disertaciones

Así, la música permite también segmentar los públicos objetivos, porque habla en un idioma común a los colectivos, fortaleciendo la identificación emocional de los individuos (Sánchez Pardo, Megías Quirós \& Rodríguez San Julián, 2004). Esto es aprovechado por los anunciantes para los que "el objetivo es conseguir que el fenómeno fan de la música popular se traslade a la marca para conseguir clientes comprometidos a cambio de ofrecerles una sensación de exclusividad" (Sánchez Olmos, 2009, p. 57), tal y como han hecho Absolut o Heineken con el uso estratégico de la música en sus estrategias publicitarias (Lusensky, 2011).

Esta capacidad de la música de estimular estados de ánimo, experiencias y emociones es una de las más relevantes en públicos objetivos como el de los jóvenes, pues la emocionalidad es un recurso muy utilizado en la publicidad dirigida a este segmento (y ellos lo valoran mucho), siendo interpretado como muestra de interés por sus sentimientos y por su propia vida.

En esa búsqueda de los anunciantes por recoger la realidad juvenil, se tiene en cuenta que los jóvenes son los mayores consumidores de música; componente que forma parte indispensable en sus actividades habituales, en ocasiones como acompañamiento omnipresente en sus vidas. De esta forma, incorporar elementos como la música, las tecnologías y otros códigos juveniles a la publicidad favorece la empatía y aumenta el impacto (Sánchez Pardo, et al., 2004).

Además, los jóvenes son un público clave para anunciantes y marcas, puesto que son nuevos consumidores que empiezan a probar todo tipo de productos/servicios con menores frenos que otros segmentos de mayor edad.

La música se ha convertido en el idioma internacional de los jóvenes, y quizá sea el mejor camino para captar su atención entre tantos anuncios parlantes en la radio y en la televisión. Las músicas bien empleadas pueden llegar a convertirse para los productos en verdaderas canciones superventas (Santacreu, 2002, p. 76).

Los jóvenes son también los que más se movilizan en todo lo que constituye el sector de la música y las marcas. Conscientes de ello, estas tratan de aprovecharlo en sus estrategias de comunicación. Hoy un grupo musical de éxito puede aportar un enorme valor a una marca y, al mismo tiempo, la música puede alcanzar una enorme repercusión por la repetición y amplificación conseguida por la campaña. La publicidad puede llegar a rescatar determinadas músicas y proporcionarles una segunda vida (Santacreu, 2002; Fraile, 2012).

\section{Clasificación de la música en la publicidad}

Para esta investigación sobre las claves de éxito de la música en la publicidad que más atrae a los jóvenes, resulta necesario clarificar la tipología de música y la clasificación elegida para este estudio. En este sentido, no parece existir una tipificación científica reconocida; la más extendida contempla los dos siguientes grandes tipos: música original, compuesta específicamente para la publicidad; y música preexistente, escogida y adaptada a la campaña, sufragando los derechos correspondientes (Bassat, 1993; Fernández Gómez, 2002; Guijarro \& Muela, 2003; Barsa \& Montañés, 2006; Palencia-Lefler, 2009).

Saborit (1994) realiza su propia clasificación para el medio televisión, estableciendo cuatro géneros: serie tonal, serie no tonal, popular culta y popular. Y si bien se trata de una tipología que agrupa músicas que se exponen en este medio, no es una clasificación específica para la publicidad. Santacreu (2002) establece otra taxonomía basada en la semiótica y la operativización de los valores musicales. Por su parte, Ruth y Spangardt (2017) utilizan una interacción de términos entre publicidad con música, publicidad con músicos, música con 
publicidad y publicidad para músicos, que abre nuevos campos para la investigación, pero que se aleja de los fines del presente estudio.

En esta investigación se utiliza la clasificación propuesta por Palencia-Lefler (2009), basada en la de Barsa y Montañés (2006), que maneja las mismas categorías musicales y que aplica en dos estudios posteriores (Palencia-Lefler, 2010, 2017).

Tabla 1. Clasificación de la música en publicidad: original y preexistente

\begin{tabular}{|c|c|c|}
\hline Clasificación & Tipo & Descripción \\
\hline \multirow{4}{*}{ Original } & $\begin{array}{l}\text { Jingle-marca o canción } \\
\text { publicitaria }\end{array}$ & $\begin{array}{l}\text { Compuesta originalmente con letra y música elaborada específicamente para } \\
\text { un anuncio. En la letra se puede incluir marca, nombre producto o beneficios. }\end{array}$ \\
\hline & Jingle-adsong & $\begin{array}{l}\text { Canción compuesta para un anuncio en la que, a diferencia del jingle-marca, } \\
\text { su letra no es comercial, no hace referencias al producto o servicio anunciado. }\end{array}$ \\
\hline & $\begin{array}{l}\text { Logo musical/sintonía } \\
\text { corporativa }^{2}\end{array}$ & $\begin{array}{l}\text { Música exclusivamente instrumental, lo que lo diferencia del jingle-marca } \\
\text { cantado. Se trata de una música compuesta para que los oyentes identifiquen } \\
\text { a la marca cuando la escuchan. }\end{array}$ \\
\hline & Música incidental & $\begin{array}{l}\text { Música sin letra que acompaña a las imágenes, que no busca tanto que se } \\
\text { recuerde la marca, sino reforzar el efecto global del spot publicitario. }\end{array}$ \\
\hline \multirow{4}{*}{ Preexistente } & Fono & $\begin{array}{l}\text { También denominada 'máster'. Grabación original de la que se compran } \\
\text { todos los derechos de autor y fonográficos para utilizarla en un mensaje } \\
\text { publicitario sin modificación alguna. }\end{array}$ \\
\hline & Versión cover & $\begin{array}{l}\text { Grabación prácticamente igual que la original, realizada para adaptarla a la } \\
\text { métrica, tiempo y duración del anuncio, además de no tener que pagar los } \\
\text { derechos fonográficos. }\end{array}$ \\
\hline & Versión libre & $\begin{array}{l}\text { Cercana al cover, pero en este caso se cambian elementos para adaptarla } \\
\text { a los objetivos del mensaje publicitario: la letra, el tiempo, los arreglos, la } \\
\text { interpretación, etc. }\end{array}$ \\
\hline & $\begin{array}{l}\text { Música de librería o } \\
\text { archivo sonoro }\end{array}$ & $\begin{array}{l}\text { También denominada por su término inglés, music library o como banco de } \\
\text { música, archivo musical o música de archivo. Archivos sonoros que no tienen } \\
\text { derechos de autor vigentes. }\end{array}$ \\
\hline
\end{tabular}

Fuentes: Palencia-Lefler (2009) y Barsa y Montañés (2006).

Además, para este estudio se estableció la necesidad de contemplar la clasificación de música utilizada en análisis fílmico, de Fernández y Martínez (1999) (tabla 2).

2 Este tipo unifica de alguna manera las categorías propuestas por Barsa y Montañés (2006), instrumental genérica y sound alike. 


\section{DISERTACIONES}

ESTUDIOS

El papel del sonido en la comunicación: contribución, funciones y efectos

ISSN: 1856-9536

Doi: http://dx.doi.org/10.12804/revistas.urosario.edu.co/disertaciones/a.6537

Volumen 12, Número 2 / Julio-diciembre 2019

Versión PDF para imprimir desde

http://revistas.urosario.edu.co/index.php/disertaciones

Tabla 2. Clasificación de la música en publicidad: diegética y no diegética o extradiegética

\begin{tabular}{|l|l|}
\hline \multicolumn{1}{|c|}{ Clasificación } & \multicolumn{1}{c|}{ Descripción } \\
\hline Música diegética & $\begin{array}{l}\text { Música que surge de la propia acción, con un carácter totalmente realista al formar parte de la } \\
\text { escena. Los protagonistas pueden ser intérpretes de la música o se puede estar desarrollando } \\
\text { una actuación musical, por ejemplo, al mismo tiempo que se desarrolla la acción. Limita las } \\
\text { manipulaciones efectistas al tener el espectador control del origen musical que escucha. }\end{array}$ \\
\hline $\begin{array}{l}\text { Musica no diegética } \\
\text { o extradiegética }\end{array}$ & $\begin{array}{l}\text { Música que no surge de la acción y se inserta en la banda sonora para conseguir un efecto estético } \\
\text { y de refuerzo emocional. Es una convención que no existe en la vida real, pero ayuda a dar mayor } \\
\text { efectismo a las escenas. Por ejemplo, en escenas de terror o misterio producen mayor expectación y } \\
\text { tensión en el espectador. }\end{array}$ \\
\hline
\end{tabular}

Fuente: Fernández y Martínez (1999).

Conformemente, esta investigación explora las claves del éxito de la música en la publicidad audiovisual que valoran los jóvenes, atendiendo a los resultados de un estudio longitudinal llevado a cabo para el festival publicitario Jóvenes Tocados por la Publicidad, con distintas categorías de premios, entre ellas el galardón a la mejor música-sonido. En concreto, la investigación pretende conseguir los siguientes objetivos:

- Conocer en profundidad los spots que los jóvenes han seleccionado y premiado a la mejor música-sonido entre 2005 y 2016.

- Determinar cuáles son las principales claves de éxito que explican esta elección de los jóvenes.

- Averiguar cómo se distribuyen las músicas de los anuncios según las clasificaciones mencionadas para el estudio.

\section{Método}

Esta investigación se fundamenta en el estudio longitudinal efectuado para los premios del festival Jóvenes Tocados por la Publicidad (certamen que en su origen fue anual y que a partir de 2013 se hace bianual), organizado por la Facultad de Comunicación y Artes de la Universidad Nebrija de Madrid. Se trata de un festival universitario que, desde 1998, viene premiando los spots emitidos en medios audiovisuales de cada año de edición del festival. El certamen otorga las siguientes distinciones: Gran Tocado (anuncio del año), Joven Tocado (anuncio en el que los jóvenes se ven mejor reflejados, más identificados), Tocado Idea Creativa, Tocado Slogan-Claim, Tocado Imagen-Realización, Tocado Social y Tocado Música-Sonido, este último objeto de análisis en este trabajo.

El presente estudio analiza los tres anuncios nominados en la categoría música-sonido en las últimas diez ediciones del certamen, desde 2005 a 2016, lo que supone un total de 30 anuncios.

Para la selección de estos premios, en cada edición se realiza una investigación siguiendo una metodología triangular, utilizando métodos cuantitativos y cualitativos, que se aplican a una muestra representativa de estudiantes de la Facultad de Comunicación y Artes.

La metodología cuantitativa es empleada fundamentalmente para obtener datos de relevancia de la publicidad audiovisual emitida en España, además de para aproximarnos descriptivamente a los anuncios seleccionados por 


\section{DISERTACIONES}

ESTUDIOS

El papel del sonido en la comunicación: contribución, funciones y efectos

ISSN: 1856-9536

Doi: http://dx.doi.org/10.12804/revistas.urosario.edu.co/disertaciones/a.6537

Volumen 12, Número 2 / Julio-diciembre 2019

Versión PDF para imprimir desde

http://revistas.urosario.edu.co/index.php/disertaciones

los estudiantes. Este método se complementa con el cualitativo para profundizar en las elecciones y encontrar explicación a las razones que llevaron a los participantes a seleccionar determinadas campañas para cada uno de los premios que otorga el festival.

La herramienta elegida para la metodología cuantitativa ha sido el cuestionario autoadministrado presencial, aunque en las dos últimas ediciones también se ha implementado online, con un índice de respuesta poco significativo. Dicho cuestionario se utiliza fundamentalmente para medir la notoriedad a través del recuento de los spots más votados, por lo que la información que se obtiene no se somete a ningún tipo de análisis más pormenorizado, que será el principal objetivo de la metodología cualitativa.

El proceso de medición cuantitativa se realiza en tres fases sucesivas: recuerdo espontáneo, recuerdo sugerido y visionado de las campañas más recordadas.

La fase de recuerdo espontáneo (cuestionario en anexo I) tiene como principal objetivo conocer los anuncios que de forma espontánea recuerdan los participantes. Para ello se les pide que identifiquen, con sus propias descripciones, los cinco spots que antes evoquen y que de ellos indiquen los tres que más les hayan gustado. Tras el análisis de los resultados de esta fase, se elabora una lista que será sobre la que tendrán que seleccionar los anuncios más atrayentes en la fase siguiente, la de recuerdo sugerido.

La fase de recuerdo sugerido (cuestionario en anexo II) tiene como propósito seguir profundizando en la notoriedad y atractivo de las campañas publicitarias y requiere, en primer lugar, que los participantes completen el listado de anuncios que se les propone, si creen que falta algún spot que consideren relevante y no está en el listado. Una vez completado este, se procede a seleccionar de nuevo los spots que consideren más atractivos y a explicar las razones de su elección. El listado de spots propuesto en el cuestionario se presenta por orden alfabético y se hacen dos versiones A (ordenado de la A a la Z) y B (ordenado de la Z a la A), con el objetivo de controlar el sesgo que pudiera derivarse de la posición de presentación. Los resultados de esta selección son los que pasan a la siguiente etapa de visionado.

En la última fase del cuantitativo, los alumnos tienen que ver los anuncios seleccionados en la fase anterior y responder a un cuestionario de visionado (anexo III), en el que ya tienen que elegir los mejores spots para cada una de las categorías de premios que otorga el festival, de donde saldrán los nominados y ganadores finales.

Cuando ya se conocen los resultados para cada uno de los premios, se investigan cualitativamente con el objetivo de entender las razones de la elección mediante grupos de discusión. Esta técnica nos parece la más adecuada a la hora de valorar la publicidad en tanto se dirige a grupos sociales determinados. Como bien señala Alonso (1998), el grupo de discusión indaga sobre representaciones sociales a partir de la confrontación discursiva de los participantes. También porque, como plantea Callejo (2001), mediante esta técnica cada participante aporta no solo la visión general que tiene de la situación que se investiga, sino además lo que los participantes son y sienten personalmente, en este caso los jóvenes, para otorgar los premios con los que se sienten identificados.

En los grupos de discusión se invita a los estudiantes a debatir sobre el significado y sentido de cada uno de los premios del certamen y sobre los spots elegidos en cada categoría. En primer lugar, se explora de forma espontánea y luego se visionan de nuevo los anuncios más valorados en la última fase del cuantitativo. Una vez finalizada la dinámica de grupo, se les pasa un breve cuestionario (anexo IV) en el que los estudiantes deciden la mejor campaña para cada categoría de premios. Se realizan dos grupos de discusión con jóvenes que participaron en la anterior fase de visionado. 
En cada edición, el tamaño de la muestra cuantitativa ha ido variando en función del número total de alumnos matriculados en la Facultad de Comunicación y Artes, con un límite de error muestral entre el $1 \%$ y el $5 \%$, lo que ha dado una media en todas las ediciones de entre 100 y 150 estudiantes participantes presenciales. Como ya se ha señalado, en las dos últimas ediciones el cuestionario se ha podido responder online, pero los resultados no son significativos ni en cuanto al número de encuestas recibidas, ni en cuanto a la calidad de las respuestas contrastadas con las presenciales.

En la muestra cualitativa, formada por los grupos de discusión, se ha contado con la asistencia de entre 6 y 9 estudiantes en cada grupo. El único requisito es el de haber participado al menos en la fase de visionado. La duración de los grupos ha sido de entre una hora y media y dos horas, y se ha grabado la discusión para su análisis posterior.

\section{Resultados}

\section{El triunfo de la sencillez y emotividad}

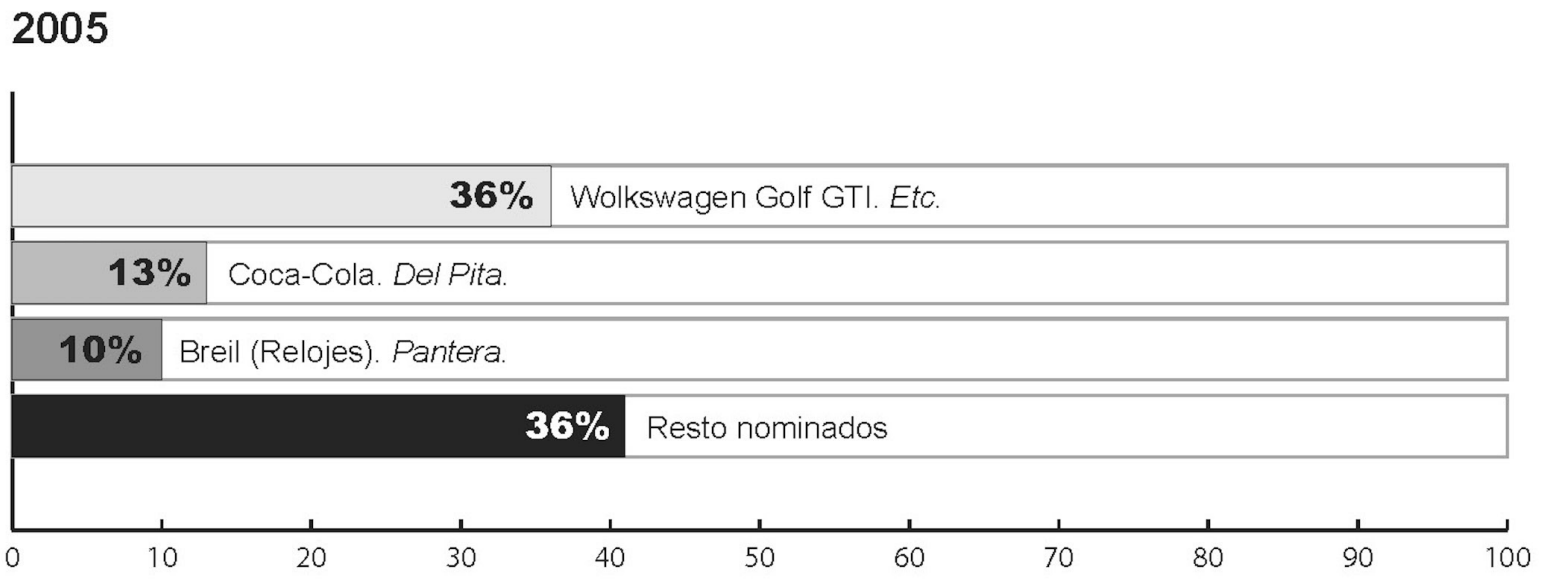

Figura 1. Anuncios nominados a la mejor música-sonido edición 2005

En 2005, las tres campañas seleccionadas para el premio de música-sonido alcanzaron casi un $60 \%$ de la muestra, siendo la de Golf la vencedora con un $36 \%$ de los votos.

Las músicas de los spots de Volkswagen y Breil son preexistentes y extradiegéticas, y la de Coca-Cola es original y diegética.

La canción ganadora de la edición es una música fono, Everytime I see you (Cada vez que te veo), interpretada por New Order. Se trata de una música emotiva y nostálgica, que apoya el mensaje e imágenes mostrando la evolución del mítico modelo Golf, desde 1974 a 2004.

La segunda canción nominada es diegética, interpretada por el protagonista, y muy distinta a la anterior, que la duplica en votos (figura 1). Es una música original, jingle-adsong, popularizada por Orleya, y creada especialmente para la campaña. La melodía elegida es divertida, con tintes étnicos y transmite bien los valores de la marca: 


\section{DISERTACIONES}

ESTUDIOS

El papel del sonido en la comunicación: contribución, funciones y efectos

ISSN: 1856-9536

Doi: http://dx.doi.org/10.12804/revistas.urosario.edu.co/disertaciones/a.6537

Volumen 12, Número 2 / Julio-diciembre 2019

Versión PDF para imprimir desde

http://revistas.urosario.edu.co/index.php/disertaciones

igualdad, universalidad, unidad, felicidad y confianza. El título enigmático de la canción, Del pita del, desvela parte de su significado: "Sigue el dictado de tu espíritu", eslogan del anuncio.

La tercera canción nominada, del anuncio de la marca de relojes Breil, es Tangled up in me (Líate conmigo), interpretada por Skye Sweetnam, una música fono que ilustra las imágenes, aunque las emociones que transmite no lleguen a conectar tanto con los jóvenes como las anteriores nominadas.

En esta edición, los consultados apuestan por premiar la sencillez y la emotividad de la música del anuncio de Volkswagen, frente a la diversión y la sofisticación que representan las otras dos nominadas.

\section{Transcendencia frente a ligereza}

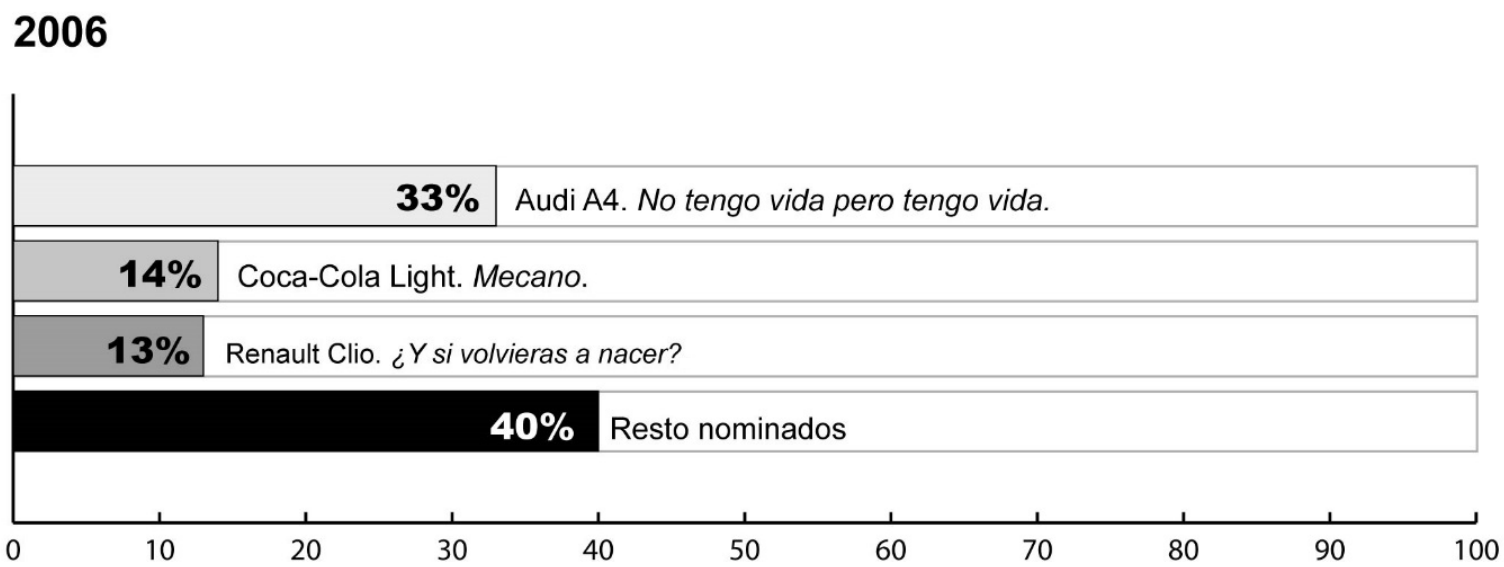

Figura 2. Anuncios nominados a la mejor música-sonido edición 2006

En 2006, los porcentajes de votación indican un comportamiento similar a la edición anterior: nominaciones que acaparan el $60 \%$ y una canción ganadora que alcanza más de la mitad de los votos de los nominados.

Las tres canciones más votadas son preexistentes, fono la ganadora y las otras dos covers. La nominada para Coca-Cola Light se sitúa en el universo diegético del spot y las otras dos en el extradiegético.

La canción ganadora, Ain't got no, I got life (No tengo, pero tengo vida), de Nina Simone es una música emotiva cuya letra sirve como copy de la campaña publicitaria. En ella se contrapone lo que nos puede faltar en la vida frente a lo que se tiene de verdad, uno mismo, convirtiéndose en un himno a la esperanza y a la propia existencia, algo que conecta muy bien con lo que los jóvenes sienten.

La segunda nominada, a cierta distancia de la ganadora, es una versión cover de canciones muy conocidas del grupo español Mecano, que se emitió coincidiendo con el éxito del musical Hoy no me puedo levantar, que inspira toda la campaña publicitaria. Los valores y emociones que transmite la música, en total conexión con las imágenes, son los de la alegría de vivir, la jovialidad y la despreocupación.

La tercera canción nominada es también preexistente, se trata de la conocida melodía instrumental de sintetizador Popcorn (Palomitas de maíz), que acompaña a unas imágenes divertidas y un tanto absurdas. Es una canción tecno que se supone fue la primera creada por un programa de computadora específico para componer música. La 


\section{DISERTACIONES}

ESTUDIOS

relación de la música con las imágenes se establece a partir del absurdo y la simpatía, que conectan con la facilidad de manejo del coche y la simplicidad y el disfrute de la vida. ${ }^{3}$

Así pues, en esta edición, el protagonismo de la música ganadora se centra en los valores de superación que transmite la canción de Nina Simone “... nos tenemos a nosotros mismos, más allá del mundo material...”, un mensaje en el que se percibe profundidad frente a otro tipo de signos más identitarios de los jóvenes, como los que, sin duda, reflejan las otras dos campañas con las que compite por el premio: la simplicidad y el disfrute de la vida.

\section{Diversión y sensibilidad}

\section{7}

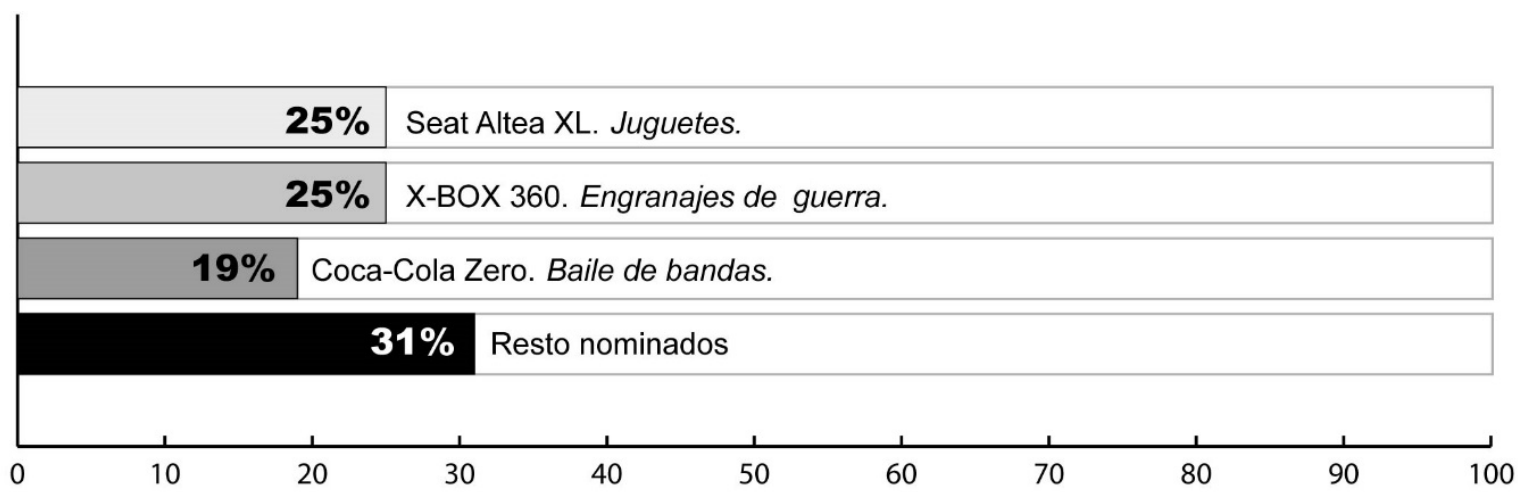

Figura 3. Anuncios nominados a la mejor música-sonido edición 2007

En 2007, los tres spots seleccionados suman casi el $70 \%$ de los votos de los jóvenes, empatando dos de ellos y sumando el $50 \%$ de esta edición, aunque con canciones de estilos muy diferentes.

De las tres canciones nominadas, dos son músicas preexistentes (cover y fono) y una es original (jingle-adsong). Respecto a la otra variable analizada, de las tres melodías una es diegética y dos extradiegéticas.

La canción del anuncio Seat Altea XL, When Johnny comes marching home (Cuando Johnny viene marchando a casa), versionada por Tijuana in Blue, es una melodía popular, muy conocida por las películas americanas y de la que también se han hecho adaptaciones infantiles, que son sobre las que se basan los arreglos de esta melodía, versión cover con letra en español. Se trata de una canción mítica que transmite emociones sugerentes, al tiempo que divertidas, sobre el refugio y la seguridad que proporciona la familia; sentimientos que los jóvenes valoran y con los que les gusta identificarse.

3 Si bien estas dos últimas campañas no consiguen el premio en la categoría de mejor música-sonido de esta edición (2006), ambas son nominadas al premio Joven Tocado, uno de los más valorados del festival, en el que los jóvenes se ven mejor reflejados: más 'normales' y sencillos, como los que aparecen en el anuncio de Coca-Cola; o jóvenes diferentes, más extraños, como los protagonistas del de Clio. 


\section{DISERTACIONES}

ESTUDIOS

El papel del sonido en la comunicación: contribución, funciones y efectos

ISSN: 1856-9536

Doi: http://dx.doi.org/10.12804/revistas.urosario.edu.co/disertaciones/a.6537

Volumen 12, Número 2 / Julio-diciembre 2019

Versión PDF para imprimir desde

http://revistas.urosario.edu.co/index.php/disertaciones

Por su parte, la canción del anuncio Xbox 360, Mad world (Loco mundo), de Gary Jules, es una música fono también muy conocida por los jóvenes. Se trata de una balada triste y preciosa que acompaña a las imágenes del héroe del videojuego en su recorrido por una ciudad desolada.

La tercera nominada es la canción original Baile de bandas, compuesta por Carlos Jean para Coca-Cola Zero; una nueva versión de la campaña Sensación de Vivir que la marca lanzó en los años ochenta. En esta, dos grupos de jóvenes rebeldes comienzan un duelo de baile al estilo de la película West side story y acaban entremezclándose evidenciando el sabor idéntico del nuevo refresco sin azúcar y el del tradicional. La música se centra en los valores de la entonces nueva Coca-Cola Zero: juventud, frescura, fidelidad al sabor tradicional, pero destinado a jóvenes inconformistas que se cuidan. En este caso, a diferencia de los anteriores, la música se ha considerado diegética, al ser parte de la acción al más puro estilo del género musical.

Así pues, en esta edición, la diversión infantil y la belleza de una melodía desconsolada y cargada de emotividad son a partes iguales las preferidas por los jóvenes por encima de otras composiciones.

\section{La belleza y poesía}

\section{8}

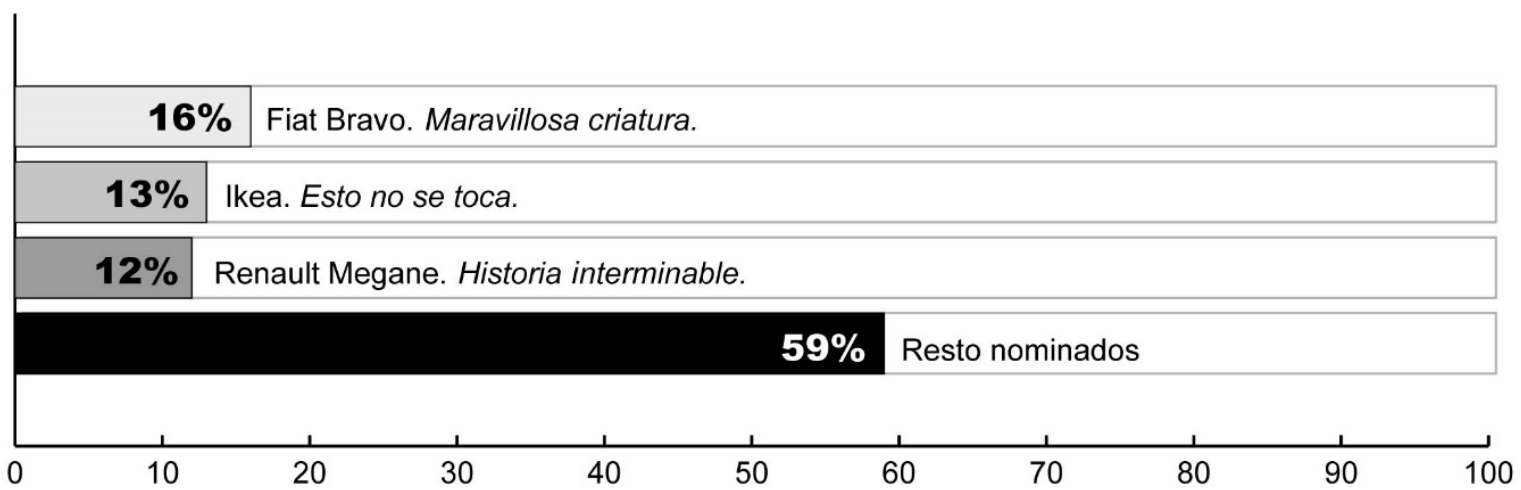

Figura 4. Nominados a la mejor música-sonido edición 2008

En el año 2008 se observa menor concentración de votos en las tres campañas nominadas a la mejor música-sonido, alcanzando entre todas tan solo un $41 \%$ del cómputo final de la votación. Además, se aprecia una escasa diferencia entre ellas en cuanto a número de votos, lo que parece indicar que no hay canciones tan destacadas como claras favoritas como en ediciones anteriores.

De las tres canciones nominadas, dos son músicas preexistentes (una fono y una versión libre) y una original, un jingle-adsong. De todas ellas, la música de la marca Ikea es la única diegética, cantada a través de un megáfono, lo que le da además un timbre especial.

La música ganadora es Meravigliosa creatura (Maravillosa criatura), de Gianna Nannini, del anuncio de Fiat Bravo. Es una canción de texto poético e inspirador que da nombre a la campaña y subraya el mensaje y valores 


\section{DISERTACIONES}

ESTUDIOS

que quiere transmitir, todos ellos relacionados con el amor y el arte, de donde se desprenden sensaciones placenteras, coherentes con la exclusividad del modelo de coche que se publicita.

Solo tres puntos porcentuales por debajo se sitúa la canción del spot de la marca Ikea, que utiliza una canción original, Esto no se toca, con esto no se juega, creada por Toni M. Mir y Joaquín Molín e interpretada por Joao Oliveira y Jordi Guerrero. En este caso, los jóvenes valoran positivamente que sea una canción espontánea, divertida y que sirva de contrapunto a las imágenes transgresoras a las que acompaña. Además, la música conduce a experiencias muy cercanas a las que los jóvenes vivieron de pequeños, como es el mundo de las prohibiciones: "En el salón no se juega, en el sofá no se come", dice la canción, logrando transmitir emociones liberadoras y gratificantes entre ellos.

A solo un punto de esta segunda, se sitúa la tercera campaña nominada, la de Renault Megane, con una adaptación libre de Never ending story (Una historia interminable), de Limahl. De nuevo una campaña muy original basada en el absurdo y en el que la letra de la canción es el copy del spot y, por lo tanto, uno de los elementos centrales de este. La letra es original, divertida, rompedora y pegadiza, en la que se van entremezclando elementos de la realidad y la ficción. ${ }^{4}$

A pesar de la poca concentración de voto, en esta edición los jóvenes premian la canción más poética y de mayor belleza, más alejada de la broma y diversión de las otras dos melodías nominadas.

\section{Innovación}

\section{9}

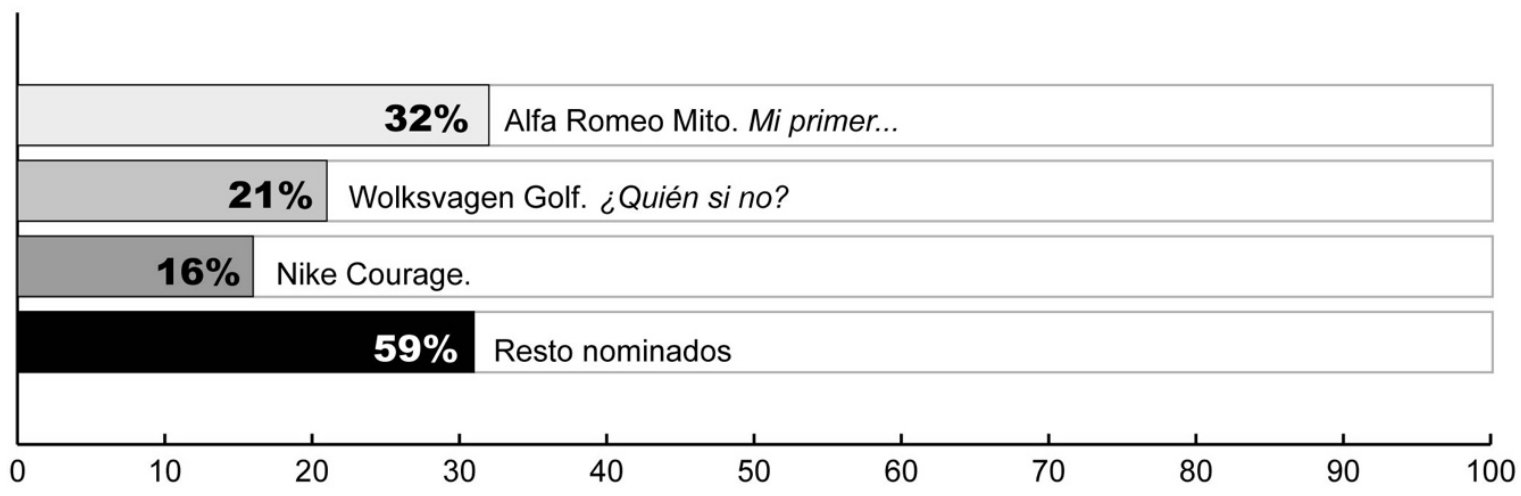

Figura 5. Anuncios nominados a la mejor música-sonido edición 2009

En esta edición de 2009, el total de los anuncios nominados alcanza una significativa relevancia con casi un $70 \%$ de votos.

4 Los dos spots nominados, aunque no premiados en esta categoría, están también entre los nominados al premio más importante del festival, el Gran Tocado. El de Renault Megane opta también al premio Idea Creativa, por lo que parecen ser dos anuncios sobresalientes entre los jóvenes, aunque en música-sonido se elija Maravillosa criatura del anuncio de Fiat Bravo. 


\section{DISERTACIONES}

\section{ESTUDIOS}

Todas las canciones seleccionadas para este premio son músicas preexistentes (fono) y extradiegéticas.

La canción ganadora, Tecnologic (Tecnológico), del grupo francés Daft Punk (2005), es prácticamente inédita para los jóvenes. A pesar de su desconocimiento, valoran que la música es coherente con la estrategia y el mensaje que transmite la campaña de Alfa Romeo, que, por primera vez, integra el enfoque transmedia y las tic en su publicidad. Así, los jóvenes premian aquí la novedad e innovación, en total sintonía con la música electrónica que se elige.

Por el contrario, la canción del spot de Volkswagen Golf es muy conocida, pues se trata del tema Eye of the tiger (Ojo del tigre) (banda sonora de la película Rocky III), interpretada por Chiara Mastroianni. La melodía, que narra el regreso del héroe, tiene una gran carga emotiva e ilustra las imágenes del anuncio sobre las que se van sobreimprimiendo datos y mensajes que comparan la relación usuario-coche con el de una pareja amorosa. Tanto la letra como la versión musical apoyan la estrategia de la campaña: la letra remite a la imagen mitológica del Golf, de larga historia, y la versión, a la relación romántica. Ambos elementos provocan fuertes identificaciones entre los jóvenes.

La tercera canción nominada, del anuncio de Nike, también es una canción conocida por los jóvenes, All these things that I've done (Todas estas cosas que he hecho), del grupo The Killers. La banda sonora repite el estribillo de la canción, "Tengo alma, pero no soy un soldado", mientras se van sucediendo imágenes de deportistas famosos alternadas con otras sobre el origen de la vida, la naturaleza, el juego y el arte, componiendo un texto narrativo sugerente, subrayado por la rebeldía que transmite la canción.

En esta edición los jóvenes valoran y prefieren, por encima de músicas conocidas y sentimientos identitarios, la innovación en la elección de la música, en sintonía con las estrategias y mensajes de las campañas.

\section{Coherencia de la música con la marca}

\section{0}

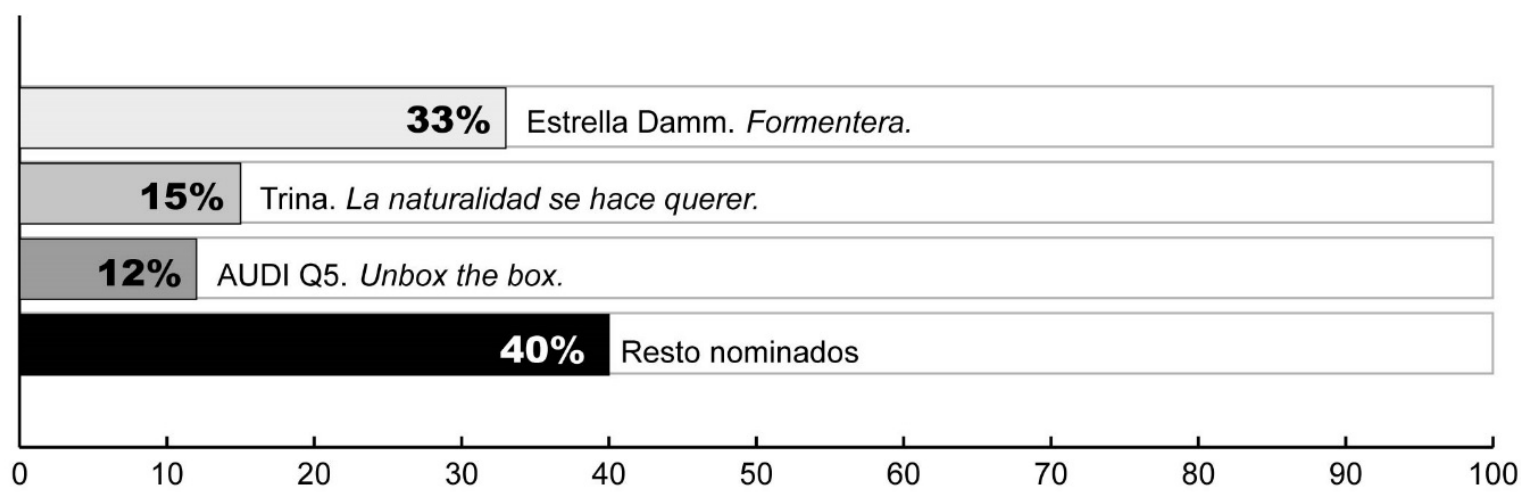

Figura 6. Anuncios nominados a la mejor música-sonido edición 2010

En 2010, el conjunto de los tres anuncios más valorados por los jóvenes acumula el $60 \%$ de las votaciones de esta edición. 


\section{DISERTACIONES}

ESTUDIOS

El papel del sonido en la comunicación: contribución, funciones y efectos

ISSN: $1856-9536$

Doi: http://dx.doi.org/10.12804/revistas.urosario.edu.co/disertaciones/a.6537

Volumen 12, Número 2 / Julio-diciembre 2019

Versión PDF para imprimir desde

http://revistas.urosario.edu.co/index.php/disertaciones

Las tres músicas seleccionadas son preexistentes (dos fonos y una versión libre) y, por primera vez, la música diegética (en los anuncios de Estrella Damm y Trina) domina a la extradiegética.

La música ganadora de Estrella Damm es fono, Summercat (Gato abandonado), de Billie the Visión \& The Dancers, se trata de una canción desconocida hasta que la campaña la convierte en un fenómeno musical del momento. La melodía tiene mucha trascendencia en el anuncio, ya que el propio grupo musical forma parte del spot, tocando la canción en una fiesta veraniega en la isla de Formentera (España). La canción marca el principio de la aventura del protagonista y vuelve a sonar como recuerdo de la experiencia mediterránea, porque "lo bueno nunca acaba si hay algo que te lo recuerda", dice el eslogan del anuncio. ${ }^{5}$

La segunda canción nominada, de la campaña de la marca Trina, es una versión libre de Yo soy aquel, del cantante español Raphael. La letra narra de forma divertida las inseguridades juveniles respecto a la elección de pareja.

La tercera nominada es Riding in my car (Montando en mi coche), de Woody Guthrie, que es de 1944-1947 y tiene un marcado toque infantil. También aquí la música es clave en la campaña: por un lado, imprime mucho ritmo; por otro, la letra es coherente con el producto. La canción consigue transmitir valores tradicionales que se contraponen a los mensajes vanguardistas y que contribuyen a aportar seguridad al modelo de coche que se anuncia (Audi Q5).

Así, en esta edición se seleccionan canciones muy diferentes entre ellas que consiguen atraer a los jóvenes por los valores que transmiten y su adaptación con los productos anunciados.

\section{Valores estables frente a modas}

\section{1}

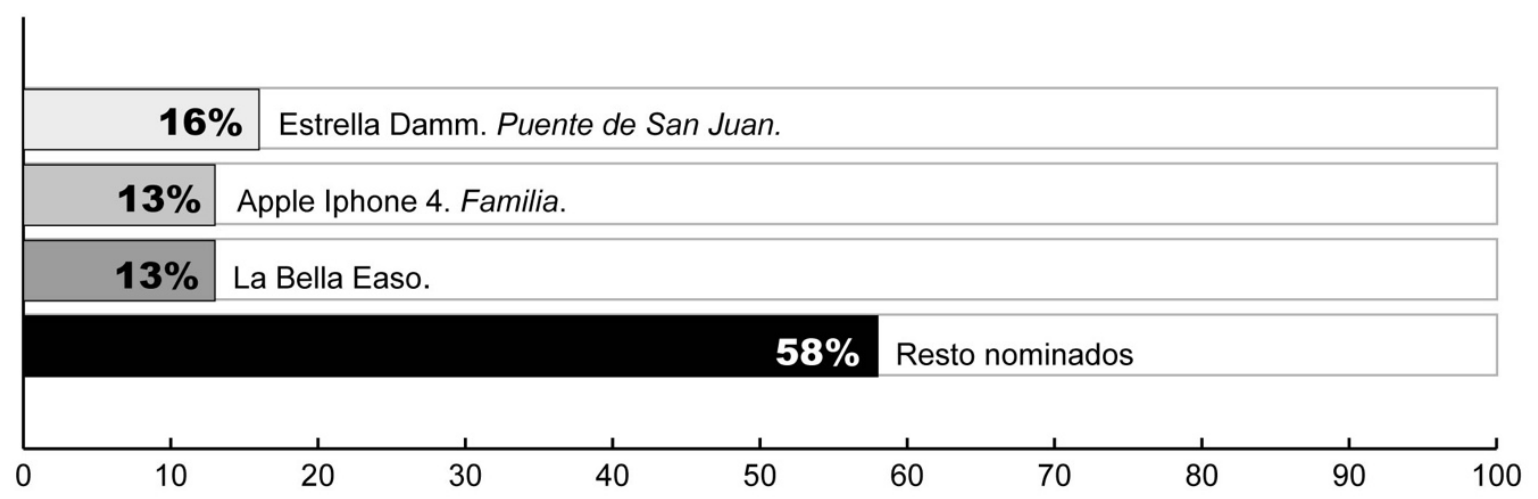

Figura 7. Anuncios nominados a la mejor música-sonido edición 2011

En esta edición de 2011, las tres campañas seleccionadas obtienen puntuaciones más bajas, similares a las de 2008.

5 Tal es el éxito del anuncio que en la misma edición recibe el premio al Joven Tocado, el anuncio que mejor identifica a los jóvenes. 


\section{DISERTACIONES}

ESTUDIOS

El papel del sonido en la comunicación: contribución, funciones y efectos

ISSN: 1856-9536

Doi: http://dx.doi.org/10.12804/revistas.urosario.edu.co/disertaciones/a.6537

Volumen 12, Número 2 / Julio-diciembre 2019

Versión PDF para imprimir desde

http://revistas.urosario.edu.co/index.php/disertaciones

Las músicas nominadas son dos preexistentes, fono, y un jingle-marca, que incursiona por primera vez en las elegidas. Se repite el fenómeno del año anterior con un mayor número de nominaciones de música diegética (Estrella Damm y La Bella Easo) que extradiegética (Apple iPhone 4).

En este año vuelve a ganar la campaña de Estrella Damm por la canción preexistente (fono) Applejack (Aguardiente de manzana), de la banda australiana The Triangles, también desconocida por el público español y que, de nuevo, el anuncio convirtió en un éxito. La marca vuelve a repetir la estrategia e introduce al grupo musical en el spot. El cambio del ritmo sonoro es el que ayuda a estructurar el relato, esta vez en la isla de Menorca (España). Así mismo, el eslogan "A veces lo que buscas está tan cerca que cuesta verlo" es precisamente el inicio de la canción, que transmite los mismos valores que la campaña del año anterior: amor, diversión, cultura mediterránea.

La canción preexistente (fono) When you're smiling (the whole world smiles with you) (Cuanto tu sonríes, el mundo sonríe contigo), de Louis Armstrong y Sy Oliver's Orchestra, es la segunda preferida por los jóvenes en esta edición, todo un clásico que ilustra el iPhone 4 como único sonido extradiegético. La letra inspira los distintos spots que componen la campaña publicitaria en los que se suceden imágenes de risas y lágrimas compartidas a través de la aplicación FaceTime. De esta forma, se combina lo más clásico de la comunicación real, cara a cara, con la tecnología más innovadora.

Empatada en segundo lugar se sitúa la campaña de la marca de magdalenas La Bella Easo, con un jingle-marca original que anuncia su producto con el eslogan "Como las de antes". Se trata de una música muy pegadiza, y de letra sencilla, que recuerda las características tradicionales del producto. La melodía, que acompaña a imágenes de familia y naturaleza, se repite en dos ocasiones y transmite valores familiares tradicionales que son apreciados por los jóvenes.

En esta edición, las tres elecciones a la mejor música ponen en evidencia la preferencia de los jóvenes por los valores tradicionales, como la familia y estilos de vida que perduran más allá de las modas.

\section{La música como reflejo de valores solidarios}

\section{2}

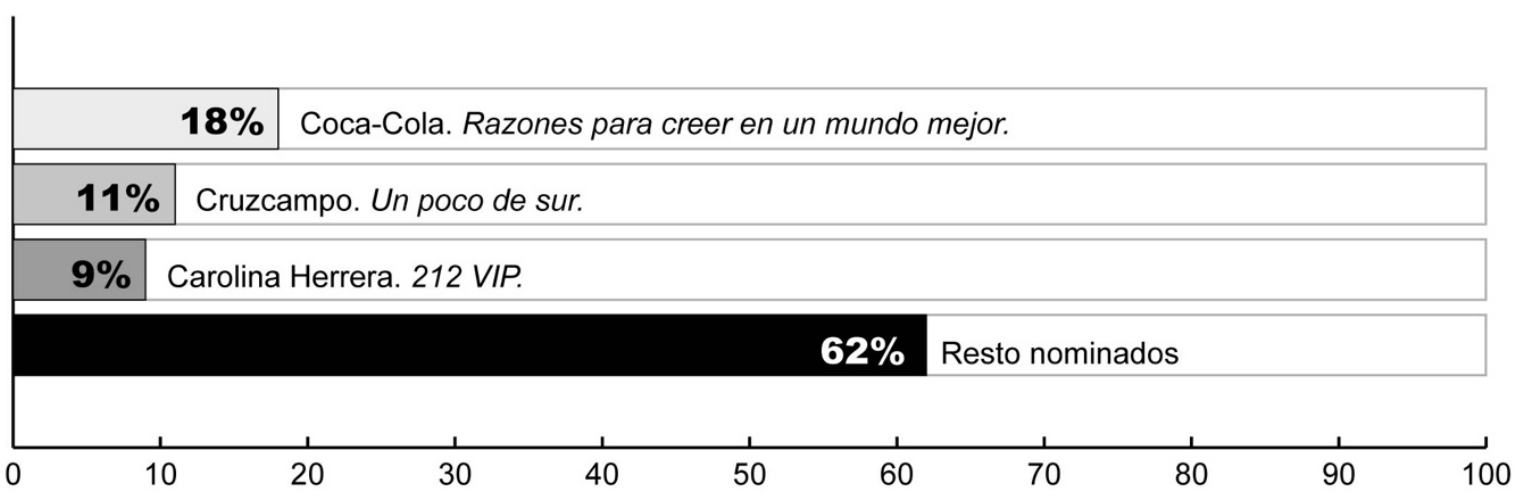

Figura 8. Anuncios nominados a la mejor música-sonido edición 2012

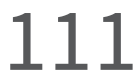




\section{DISERTACIONES}

ESTUDIOS

El papel del sonido en la comunicación: contribución, funciones y efectos

ISSN: 1856-9536

Doi: http://dx.doi.org/10.12804/revistas.urosario.edu.co/disertaciones/a.6537

Volumen 12, Número 2 / Julio-diciembre 2019

Versión PDF para imprimir desde

http://revistas.urosario.edu.co/index.php/disertaciones

En esta edición de 2012, los tres spots seleccionados consiguen una cuota de solo el $38 \%$ del total de la votación, algo más baja que en la edición anterior, aunque el anuncio ganador consigue más solvencia (figura 8).

De los tres, dos incluyen música preexistente (cover y fono) y uno original (jingle-adsong). El anuncio más votado, el de Coca-Cola, es música diegética interpretada por sus protagonistas; y los otros dos, de Carolina Herrera y Cruzcampo, son extradiegéticas.

La canción ganadora, de la campaña de Coca-Cola, es una versión de la conocida melodía Whatever (Lo que sea), del grupo Oasis, cantada por el coro de niños Young People's Chorus de Nueva York, que también protagonizan el spot. La música está presente prácticamente desde el inicio del anuncio y las imágenes reales del coro se alternan con datos y retratos sobre la situación actual en el mundo. Los niños cantan de forma natural y distendida, y transmiten emociones vinculadas a la letra de la canción: libertad, despreocupación, autenticidad. ${ }^{6}$

La segunda canción más votada, del anuncio Cruzcampo, es una música original creada por la agencia Contrapunto ввDо y la productora musical ово. La melodía suena desde el inicio del spot, mientras se narra la necesidad de armonizar el hemisferio izquierdo-norte (racional) y el derecho-sur (emocional) para mantener el equilibrio vital, si bien el espíritu del sur adquiere protagonismo hasta que el coro de voces se alza cantando la canción Todos necesitamos un poco de Sur para no perder el Norte. La música traslada valores de alegría, diversión y desenfado, muy sugerentes y desculpabilizadores para los jóvenes.

La banda musical del tercer anuncio nominado, 212 VIP de Carolina Herrera, es una canción fono, Not on the guest list (No estás en la lista de invitados), de Marco dos Santos, cuya letra sirve de relato de la campaña, que plantea el deseo de pertenecer a las élites representado en una multitud queriendo acceder a la discoteca para bailar la música disco que suena en el spot. La melodía se convierte en parte importante del objeto de deseo, una aspiración alimentada por el rechazo de algunos jóvenes que son expulsados por no estar en la lista de invitados.

Así pues, en esta edición, como en otras anteriores, los jóvenes prefieren campañas en las que la música tiene un papel protagonista y relevante, y en la que la ganadora transmite el deseo de lograr un mundo mejor, más justo y solidario, valores que los jóvenes sienten muy cercanos.

\section{3-14. Amistad, felicidad y quietud}

\section{$2013-2014$}

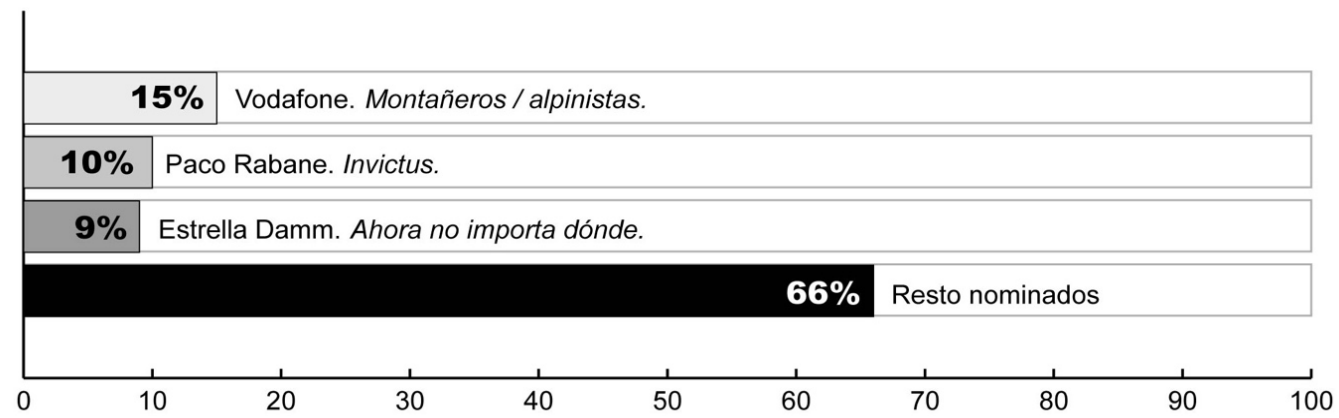

Figura 9. Anuncios nominados a la mejor música-sonido edición 2013-14

6 Esta misma campaña recibe en la edición el premio Tocado al mejor storytelling. 


\section{DISERTACIONES}

\section{ESTUDIOS}

En esta edición, las tres campañas nominadas consiguen escasa concentración de voto (solo un $34 \%$ de entre todas las seleccionadas) e, igual que en las dos ediciones anteriores, la música diegética se impone sobre la extradiegética.

Las dos primeras nominadas son preexistentes - cover la de Vodafone y fono la de Invictus- y la tercera nominada es original adsong.

La canción premiada es la versión cover de la conocida melodía Don't worry, be happy (No te preocupes, sé feliz), del anuncio de Vodafone. Los protagonistas del spot son Nico y sus amigos (los alpinistas Nicolás y Olivier Favresse y Sean Villanueva, y el fotógrafo Ben Ditto) que interpretan la música desde Mallos de Riglos (Pirineos oscenses) y dando a la música carácter diegético. Desde este lugar, el grupo se comunica a través de un móvil, cantando la canción y demostrando así la buena cobertura y calidad que ofrece la marca anunciante. La música transmite emociones de felicidad, amistad, despreocupación y sosiego.

La segunda canción nominada es la del anuncio de Paco Rabanne, Power (Poder), del rapero estadounidense Kanye West. La música, muy conocida por los jóvenes y presente desde el inicio del anuncio, trata de una mitología contraria a la clásica y al típico campeón que muestran las imágenes, expresando la rebeldía ante el desequilibrio y la locura del siglo $x \times 1 .^{\top}$

La tercera nominada es la canción Fantastic shine (Resplandeciente), del grupo Love of Lesbian, una melodía original compuesta para la marca Estrella Damm que repite la fórmula diegética de introducir a la banda musical en el universo del anuncio, aunque en esta ocasión la canción es una música original para el spot.

En esta edición, los jóvenes premian la música que refleja emociones de felicidad, amistad y despreocupación, por encima de la rebeldía.

\section{5-16. Premio a la originalidad}

\section{$2015-2016$}

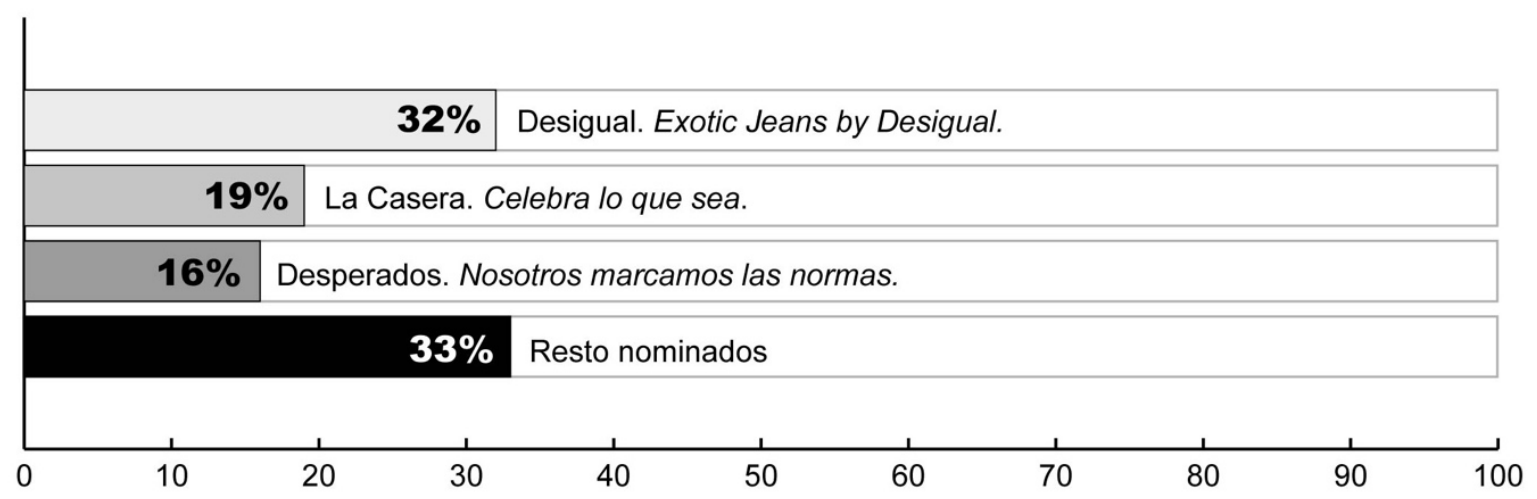

Figura 10. Anuncios nominados a la mejor música-sonido edición 2015-16

7 El anuncio obtiene el premio al Joven Tocado. La campaña con la que mejor se identifican los jóvenes. 


\section{DISERTACIONES}

ESTUDIOS

El papel del sonido en la comunicación: contribución, funciones y efectos

ISSN: $1856-9536$

Doi: http://dx.doi.org/10.12804/revistas.urosario.edu.co/disertaciones/a.6537

Volumen 12, Número 2 / Julio-diciembre 2019

Versión PDF para imprimir desde

http://revistas.urosario.edu.co/index.php/disertaciones

En esta edición, los tres primeros spots nominados concentran el $67 \%$ de los votos y, de este porcentaje, la canción ganadora gana por amplia mayoría.

De entre las tres seleccionadas, dos son músicas originales y una es preexistente, y, por primera vez, las tres canciones nominadas se inscriben en el universo diegético de las campañas.

La ganadora es la canción Hundred miles (Un centenar de millas), del grupo catalán Yall, con la colaboración de Gabriela Richardson para la marca Desigual. Se trata de un jingle-adsong, muy de 'Bollywood', y que de forma diegética invita al oyente a entrar en su universo cargado de amor y sensaciones frescas.

La segunda nominada es la versión libre de la mítica Walk like an Egyptian (Camina como un egipcio), de la banda de rock femenina estadounidense de los ochenta The Bangles, cantada por la familia Sandoval, protagonista del anuncio del refresco español La Casera. La letra es divertida y narra una celebración veraniega y familiar. Los valores que transmite son los de la unión familiar, diversión, frescura y espontaneidad.

La tercera nominada es la música de la marca de cerveza Desperados. La canción Marcamos las normas, compuesta por Terry y Wolfrank Zannaou, es todo un himno a los valores de la generación millennial ${ }^{8}$ y refleja muy claramente el insight que Desperados transmite como reflejo de un estilo de vida.

Así pues, los jóvenes en esta edición premian la originalidad de la música en los spots. Las tres campañas reflejan tanto valores tradicionales como los que identifican más a los jóvenes, ya sean reivindicativos o de amor universal.

\section{Discusión y conclusiones}

Respecto a los tipos de música preexistente, los jóvenes consideran únicamente tres: fono, cover y versión libre. De las tres, la música fono tiene mayor notoriedad, dato coincidente con la realidad del mercado, pues la mayoría de los spots elegidos pertenecen a grandes anunciantes.

En relación con los tipos de música original, se seleccionan solo dos formas, el jingle-adsong, más veces elegida, y el jingle-marca, muy marginal (solo 1 de los 30 anuncios se incluye en esta categoría).

Estos resultados también están en sintonía con la generalidad de la publicidad audiovisual.

Así, los resultados referidos a la variable preexistente-original no aportan novedades, si bien hay dos hechos reseñables: por un lado, la primacía de las canciones con letra (solo una canción, Palomitas de maíz, del anuncio Renault Clio, no cumple esta característica); y, por otro, la presencia más continuada de música original entre las preferidas por los jóvenes en las últimas ediciones del festival. Ello está favoreciendo el aspecto diegético, donde los músicos y/o protagonistas de la historia forman parte de la acción haciéndola más verdadera. Ambos aspectos invitan a continuar investigando.

Además, tal y como se aprecia en la tabla 3, los spots de la muestra que incluyen música preexistente son más del doble de los que incluyen música original (un $73 \%$ frente al $27 \%$ ), siguiendo la tendencia del mercado donde la mayoría de la publicidad audiovisual se decanta por música conocida antes que por la original. Sin embargo, en el discurso cualitativo de los participantes no se observan diferencias a la hora de preferir uno u otro tipo.

8 Precisamente esta campaña obtiene el premio Joven Tocado, la campaña con la que más se identifican los jóvenes en esta edición. 


\section{DISERTACIONES}

\section{ESTUDIOS}

El papel del sonido en la comunicación: contribución, funciones y efectos ISSN: $1856-9536$

Doi: http://dx.doi.org/10.12804/revistas.urosario.edu.co/disertaciones/a.6537

Volumen 12, Número 2/ Julio-diciembre 2019

Versión PDF para imprimir desde

http://revistas.urosario.edu.co/index.php/disertaciones

Respecto a la música de carácter extradiegético-diegético, las diferencias son menores (un $57 \%$ frente al $43 \%$ ) a favor de la extradiegética. ${ }^{9}$

Tabla 3. Distribución de anuncios según variables: preexistente-original/extradiegética-diegética

\begin{tabular}{|l|c|c|c|}
\hline \multicolumn{1}{|c|}{ Variables } & Preexistente & Original & Totales \\
\hline Extradiegética & 15 spots: $88 \%$ & 2 spots: $12 \%$ & 17 spots: $57 \%$ \\
\hline Diegética & 7 spots: $54 \%$ & 6 spots: $46 \%$ & 13 spots: $43 \%$ \\
\hline Totales & 22 spots $(73 \%)$ & 8 spots $(27 \%)$ & 30 spots $(100 \%)$ \\
\hline
\end{tabular}

Sobre la variable música diegética-extradiegética (tabla 3), las diferencias en cuanto a número de votos totales entre ambas no son muy marcadas, pero, cuando se relacionan con la variable música preexistente-original, producen discrepancias significativas.

La música preexistente (la más votada) es significativamente predominante cuando se trata de música extradiegética (un $88 \%$ frente al $12 \%$ ), mientras que, cuando se trata de música original, las diferencias son mucho menores (un $54 \%$ frente al $46 \%$ ) en el ámbito diegético, lo que es lógico, en este último caso, al estar interpretada varias veces en el propio anuncio por los actores de este. Por otro lado, también es reseñable que la forma extradiegética predomine (un $88 \%$ frente al $54 \%$ ) en la música preexistente; en cambio, la diegética prevalece de forma muy significativa (un $46 \%$ frente al $12 \%$ ) en la música original.

Veamos a continuación estas cuatro categorías de músicas, preexistente-extradiegética, preexistente-diegética, original-extradiegética y original-diegética, para los spots nominados y premiados, en cada una de las formas musicales que se mencionan (tablas 4 y 5 ).

Respecto a la música preexistente (tabla 4), la categoría extradiegética es la más votada, pero la diegética, aunque con menor número de votos, supera en galardones (un $57 \%$ frente al $40 \%$ ) a la extradiegética, tanto en tipo fono (100\%) como cover (67\%).

Tabla 4. Distribución de anuncios con música preexistente

\begin{tabular}{|l|c|c|c|c|}
\hline \multirow{2}{*}{} & \multicolumn{3}{|c|}{ Música preexistente } \\
\cline { 2 - 5 } & Nominados & Ganadores & Nominados & Ganadores \\
\hline Fono & 12 spots $(80 \%)$ & 5 spots $(42 \%)$ & 2 spots $(28 \%)$ & 2 spots (100\%) \\
\hline Cover & 2 spots $(13 \%)$ & 1 spot $(50 \%)$ & 3 spots $(44 \%)$ & 2 spots $(67 \%)$ \\
\hline Versión libre & 1 spot $(7 \%)$ & 0 & 2 spots $(28 \%)$ & 0 \\
\hline Total & 15 spots $(88 \%)$ & 6 spots $(40 \%)$ & 7 spots $(54 \%)$ & 4 spots $(57 \%)$ \\
\hline
\end{tabular}

9 No disponemos de datos del mercado en cuanto al porcentaje total de anuncios que incluyen música diegética o extradiegética, por lo que no podemos interpretar el significado de esta diferencia, aunque nuestra hipótesis es que el porcentaje de música extradiegética en los anuncios es superior a la diegética. 


\section{DISERTACIONES}

\section{ESTUDIOS}

El papel del sonido en la comunicación: contribución, funciones y efectos

ISSN: 1856-9536

Doi: http://dx.doi.org/10.12804/revistas.urosario.edu.co/disertaciones/a.6537

Volumen 12, Número 2 / Julio-diciembre 2019

Versión PDF para imprimir desde

http://revistas.urosario.edu.co/index.php/disertaciones

Cabe destacar también que la música diegética está más presente, concentrándose en las últimas ediciones del festival.

En cuanto a la música original (tabla 5), la categoría extradiegética solo consigue dos nominaciones y en la forma adsong, lo que representa un $12 \%$ de elección sobre el total de los 17 spots seleccionados en esta modalidad. Así pues, su representación es baja comparativamente con el $88 \%$ que consigue esta categoría en música preexistente. Tampoco consigue ningún galardón. Por su parte, la diegética consigue estar representada en música original con 6 spots nominados, lo que representa un $46 \%$ sobre los 13 que se eligen en esta categoría, aunque solo un spot consigue el galardón. La mayoría de las nominaciones se concentran en la forma adsong (83\%), si bien la forma jingle-marca logra también una nominación (7\%), algo llamativo teniendo en cuenta que es un estilo poco habitual en la actualidad.

Tabla 5. Distribución de anuncios con música original

\begin{tabular}{|c|c|c|c|c|}
\hline \multicolumn{5}{|c|}{ Música original } \\
\hline & \multicolumn{2}{|c|}{ Extradiegética } & \multicolumn{2}{|c|}{ Diegética } \\
\hline & Nominados & Ganadores & Nominados & Ganadores \\
\hline Adsong & 2 spots $(100 \%)$ & 0 & 5 spots $(83 \%)$ & 1 spot (7\%) \\
\hline Jingle & 0 & 0 & 1 spot $(7 \%)$ & \\
\hline Total & 2 spots (12\%) & & 6 spots $(46 \%)$ & 1 spot $(20 \%)$ \\
\hline
\end{tabular}

Al igual que se ha señalado en preexistente, en la categoría de música original, la diegética está más presente y concentrada en las últimas ediciones del festival. En la última edición que analizamos, las tres canciones nominadas ( 2 originales y 1 preexistente) se incluyen en la categoría de música diegética.

Conformemente, parece que existe una tendencia entre los jóvenes a valorar la música diegética en la publicidad, ya sea que se trate de música original o de preexistente. Y aunque todavía se necesita una mayor investigación para verificar estos resultados, de momento se establece una hipótesis inicial y es que es posible que al introducir la música en la trama interna del anuncio, se consiga favorecer los procesos de identificación de los jóvenes, además de una percepción de mayor coherencia de todos los elementos que configuran su universo narrativo.

De confirmarse esta suposición, sería interesante plantearse los tipos de música diegética que resulten más atractivos para la publicidad.

Se evidencia, pues, que el campo de la música en la publicidad es muy amplio y todavía poco explorado, y más en la sociedad digital cuando las marcas necesitan aumentar la emocionalidad de sus mensajes para ser recordadas por sus audiencias. Y es precisamente en este terreno donde la música cumple un papel fundamental.

En consecuencia, y según los resultados de esta investigación, la diferenciación entre las categorías tradicionales, música preexistente y original, no resultan significativas para los jóvenes, como tampoco lo son las distintas modalidades que se incluyen en ellas (fono o cover, jingle-adsong o jingle-marca). En cambio, las categorías de música diegética y extradiegética sí resultan relevantes, y se aprecia una clara tendencia de nuestros jóvenes hacia lo diegético, tanto en relación con la música preexistente como en la original. 


\section{DISERTACIONES}

ESTUDIOS

El papel del sonido en la comunicación: contribución, funciones y efectos

ISSN: $1856-9536$

Doi: http://dx.doi.org/10.12804/revistas.urosario.edu.co/disertaciones/a.6537

Volumen 12, Número 2 / Julio-diciembre 2019

Versión PDF para imprimir desde

http://revistas.urosario.edu.co/index.php/disertaciones

Además, no parece que el estilo de música sea un factor relevante para conseguir atraer a los jóvenes. Las canciones seleccionadas en los diez años investigados pertenecen a una pluralidad de géneros musicales distintos: pop rock, soul, música disco, fusión, electrónica, popular, rap... Predomina el pop rock más melódico, pero solo porque en general es el más abundante en la comunicación publicitaria (Palencia-Lefler, 2009).

El conocimiento-desconocimiento de las canciones o la modernidad de estas (más antiguas o más recientes) tampoco resulta significativo en la elección de los jóvenes.

Sin embargo, sí destaca que todas las canciones seleccionadas por ellos, excepto una, tengan letra, lo que sin duda también contribuye a enriquecer el universo narrativo y emocional, que es lo que verdaderamente más interesa a los jóvenes.

A este público objetivo, lo que realmente le importa de la música en la publicidad son las emociones que le suscita y que la melodía sea coherente con lo que se cuenta en el anuncio; esa relación puede expresarse de forma sintónica o irónica, pero la música siempre debe ser un elemento principal de acompañamiento y de refuerzo a la historia, las imágenes, el mensaje y los valores.

Una gran mayoría de las canciones que los jóvenes premian en estas diez ediciones se caracterizan porque transmiten una fuerte emotividad y hablan de trascendencia, de belleza y poesía, más allá de que también haya elecciones que apunten a la diversión entre amigos o la originalidad e innovación.

Al contrario de lo que pudiera parecer, los jóvenes consultados se inclinan más por músicas con letras que comunican profundidad, demostrando una clara sensibilidad y ternura.

\section{Referencias}

1. Alonso, L. E. (1998). La mirada cualitativa en sociología. Madrid: Fundamentos.

2. Barsa, M., \& Montañés, F. (2006). Historia iconográfica de la música en la publicidad. Madrid: Fundación Autor-Sociedad General de Autores.

3. Bassat, L. (1993). El libro rojo de la publicidad. Barcelona: Random House Mondadori.

4. Callejo, J. (2001). El grupo de discusión: introducción a una práctica de investigación. Barcelona: Ariel.

5. Fernández Díez, F., \& Martínez Abadía, J. (1999). Manual básico de lenguaje y narrativa audiovisual. Barcelona: Paidós Ibérica.

6. Fernández Gómez, J. D. (2002). Aproximación conceptual a la música en publicidad audiovisual. Comunicación, (1), 161-178. Doi: http://dx.doi.org/10.12795

7. Fraile Prieto, T. (2012). Músicas para persuadir. Apropiaciones musicales e hibridaciones genéricas en la publicidad audiovisual. Comunicación, 1(10), 324-337.

8. Gómez Rodríguez, J. A. (2005). Lo que no venda, cántelo. Algunas reflexiones sobre el papel de la música en la publicidad. En M. Olarte Martínez (Ed.), La música en los medios audiovisuales. Algunas aportaciones (pp. 225-266). Salamanca: Plaza Universitaria Ediciones.

9. Guijarro, T., \& Muela, C. (2003). La música, la voz, los efectos y el silencio en la publicidad: la creatividad en la producción de sonido. Madrid: CIE Dossat 2000.

10. Lusensky, J. (2011). Sounds like branding. Londres: Bloomsbury Publishing. 
11. Palencia-Lefler Ors, M. (2009). Music in the advertising communication. Communication \& Society, 22(2), 89-108.

12. Palencia-Lefler Ors, M. (2010). Banda sonora de la publicidad televisiva española: formas, géneros y estilos musicales. Communication \& Society, 23(1), 299-318.

13. Palencia-Lefler Ors, M. (2017). Música publicitaria en España (2008-17). Observación cuantitativa sobre formas musicales en espots de Tv. Revista Mediterránea de Comunicación/Mediterranean Journal of Communication, 8(2), 25-35. Doi: https://www.doi.org/10.14198/MEDCOM2017.8.2.2

14. Ruth, N., \& Spangardt, B. (2017). Research trends on music and advertising. Revista Mediterránea de Comunicación/Mediterranean Journal of Communication, 8(2), 13-23. Doi: https://www.doi.org/10.14198/ MEDCOM2017.8.2.1

15. Saborit, J. (1994). La imagen publicitaria en televisión. Madrid: Cátedra.

16. Sánchez Olmos, C. (2009). La musicidad. Las relaciones comerciales y culturales entre la industria discográfica y la publicidad. Barcelona: Collegi de Publicitaris i Relacions Públiques de Catalunya.

17. Sánchez Pardo, L., Megías Quirós, I., \& Rodríguez San Julián, E. (2004). Jóvenes y publicidad. Valores en la comunicación publicitaria para jóvenes. Madrid: Fundación de Ayuda contra la Drogadicción (FAD)-Injuve.

18. Sánchez-Porras, M. J. (2013). La persuasión de la música en la publicidad. El ejemplo Coca-Cola. Historia y Comunicación Social, 18(Esp. dic. 2013), 349-357. Doi: http://dx.doi.org/10.5209/rev_HICS.2013.v18.44333

19. Santacreu Fernández, Ó. (2002). La música en publicidad (Tesis doctoral, Universidad de Alicante, Facultad de Ciencias Económicas y Empresariales).

20. Sedeño, A. M. (2006). La función de la música en los comerciales publicitarios. unirevista, 1(3), 1-7. 


\section{DISERTACIONES}

ESTUDIOS

El papel del sonido en la comunicación: contribución, funciones y efectos

IsSN: 1856-9536

Doi: http://dx.doi.org/10.12804/revistas.urosario.edu.co/disertaciones/a.6537

Volumen 12, Número 2 / Julio-diciembre 2019

Versión PDF para imprimir desde

http://revistas.urosario.edu.co/index.php/disertaciones

Anexo 1. Cuestionario de recuerdo espontáneo

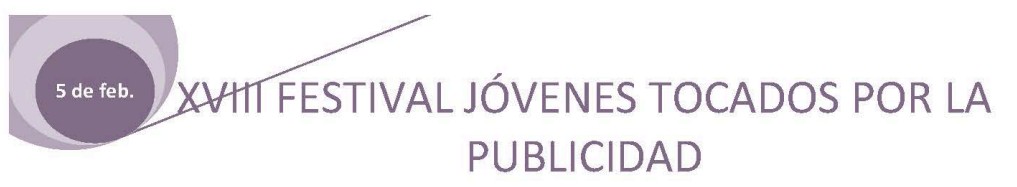

CUESTIONARIO DE VOTACIÓN: RECUERDO ESPONTÁNEO

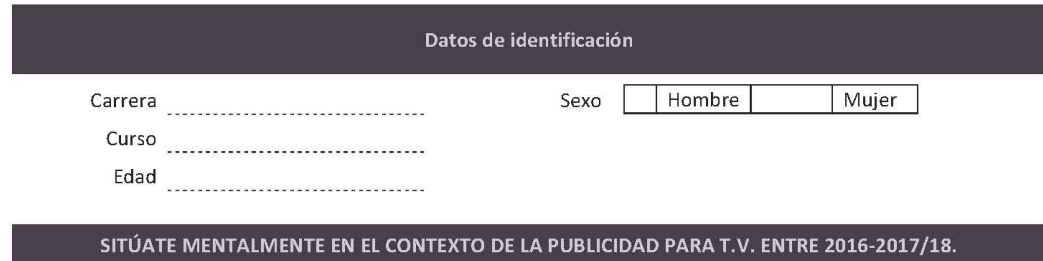

1.- ESCRIBE A CONTINUACIÓN LOS 5 SPOTS DE T.V. QUE ANTES TE VENGAN A LA CABEZA.

Específica, en la medida de lo posible, el spot concreto de la campaña a la que te refieres y la marca.

\begin{tabular}{|c|c|c|c|c|}
\hline 1 & 2 & 3 & 4 & 5 \\
\hline$\underline{\text { Spot }}$ & $\underline{\text { Spot }}$ & $\underline{\text { Spot }}$ & $\underline{\text { Spot }}$ \\
\hline$\underline{\text { Marca }}$ & $\underline{\text { Marca }}$ & $\underline{\text { Marca }}$ & $\underline{\text { Marca }}$ & Marca \\
\hline
\end{tabular}

2.- AHORA TIENES QUE ELEGIR LOS 3 SPOTS QUE MÁS TE HAYAN GUSTADO.
$\square$ Número 1
믈 2
$\square$ Número 3
$\square$ Número 4
口Número 5

3.- DESCRIBE BREVEMENTE LO QUE RECUERDES DE CADA UNO DE LOS 3 SPOTS QUE HAS ELEGIDO. Spot

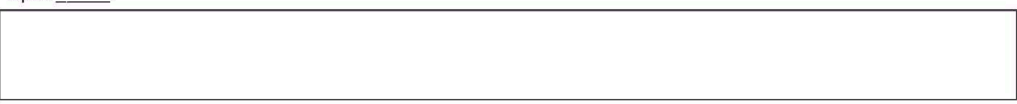

Spot___
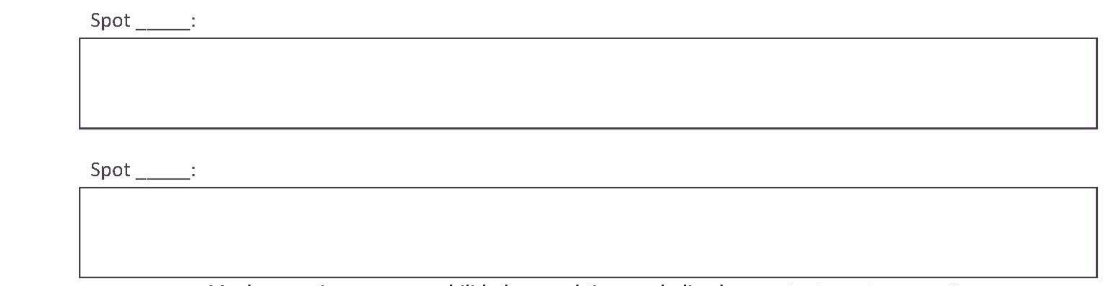

Muchas gracias por su amabilidad y por el tiempo dedicado a contestar esta encuesta

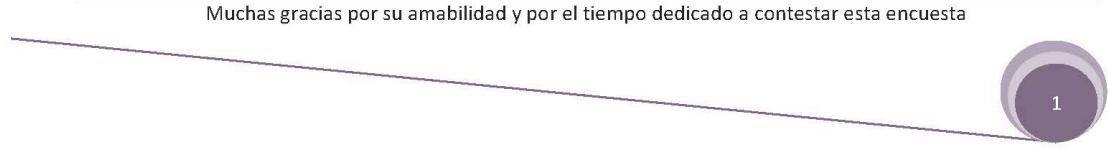




\section{DISERTACIONES}

ESTUDIOS

El papel del sonido en la comunicación: contribución, funciones y efectos

IsSN: 1856-9536

Doi: http://dx.doi.org/10.12804/revistas.urosario.edu.co/disertaciones/a.6537

Volumen 12, Número 2 / Julio-diciembre 2019

Versión PDF para imprimir desde

http://revistas.urosario.edu.co/index.php/disertaciones

Anexo 2. Cuestionario de recuerdo sugerido

\section{CUESTIONARIO DE VOTACIÓN: RECUERDO SUGERIDO}

Datos de identificación

Carrera..

Sexo \begin{tabular}{|l|l|l|l|}
\hline & Hombre & & Mujer \\
\hline
\end{tabular}

Curso

Edad

¿Has participado en la votación anterior de Recuerdo Espontáneo?

\begin{tabular}{|l|l|l|l|}
\hline SI & & NO & \\
\hline
\end{tabular}

\section{CONSIGNA: lee con atención la lista de spots. Son los spots que vosotros}

habéis seleccionado en la fase de Recuerdo Espontáneo.

1.- REPASA LA LISTA DE SPOTS Y SEÑALA CON UNA CRUZ SI LOS CONOCES O NO Y DÓNDE LO HAS VISTO, SI EN TV O INTERNETO, O EN AMBOS.

SI PIENSAS QUE HAY ALGÚN SPOT QUE DEBERÍA ESTAR INCLUIDO EN EL LISTADO Y NO ESTÁ, AÑ̃́DELO AL FINAL DE LA LISTA

\begin{tabular}{|l|l|l|l|l|l|l|}
\hline \multicolumn{2}{|c|}{ LISTA DE SPOTS MÁS VOTADOS EN RECUERDO ESPONTANEO } \\
\hline \multirow{2}{*}{ Identificación del Spot } & Marca/Producto & Conocimiento & \multicolumn{2}{|c|}{ ¿Dónde lo has visto? } \\
\hline & & Si & No & TV & Internet \\
\hline & & & & & \\
\hline & & & & & \\
\hline & & & & & \\
\hline & & & & & \\
\hline & & & & & \\
\hline & & & & & \\
\hline & & & & & & \\
\hline & & & & & & \\
\hline & & & & & \\
\hline & & & & & & \\
\hline & & & & & & \\
\hline
\end{tabular}


2.- ELIGE DEL LISTADO COMPLETO (incluyendo los que tú hayas añadido) LOS 3 SPOTS QUE MÁS TE GUSTEN, EN ORDEN DE PREFERENCIA Y COMENTA QUÉ ES LO QUE MÁS TE GUSTA DE CADA UNO DE ELLOS.

Spot 1:

SPOT

Lo que más te gusta:

(20)

Spot 2:

SPOT

Lo que más te gusta:

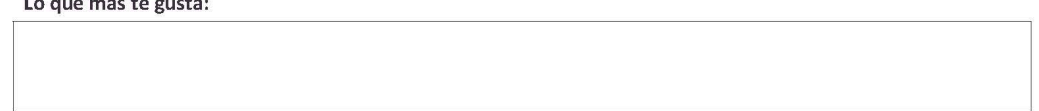

Spot 3:

SPOT

Lo que más te gusta:

MARCA

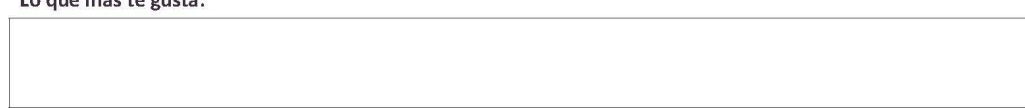

3.- SI TUVIERAS QUE DEFINIR CADA UNO DE ESOS SPOTS CON TAN SOLO TRES ADJETIVOS O PALABRAS QUE LOS DESCRIBAN, ¿¿QUÉ PALABRAS ELEGIRÍAS?

\begin{tabular}{|c|c|c|c|}
\hline & PALABRA 1 & PALABRA 2 & PALABRA 3 \\
\hline Spot A & & & \\
\hline Spot B & & & \\
\hline Spot C & & & \\
\hline
\end{tabular}

Muchas gracias por su amabilidad y por el tiempo dedicado a contestar esta encuesta

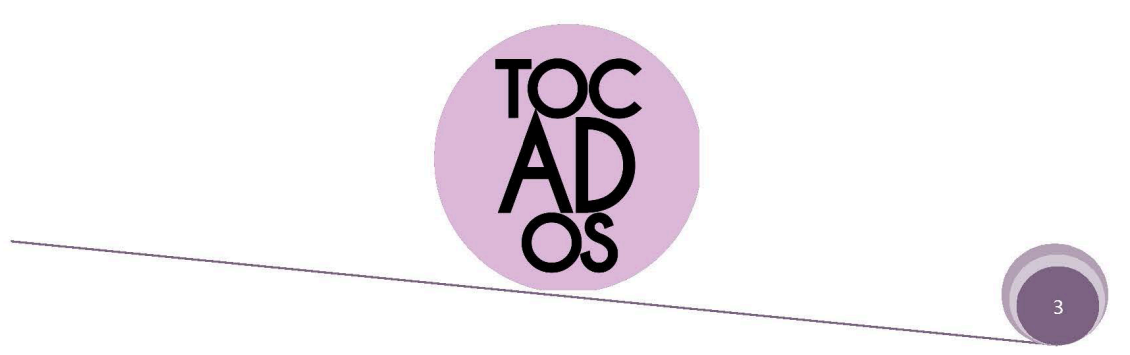




\section{CUESTIONARIO DE VOTACIÓN: VISIONADO}

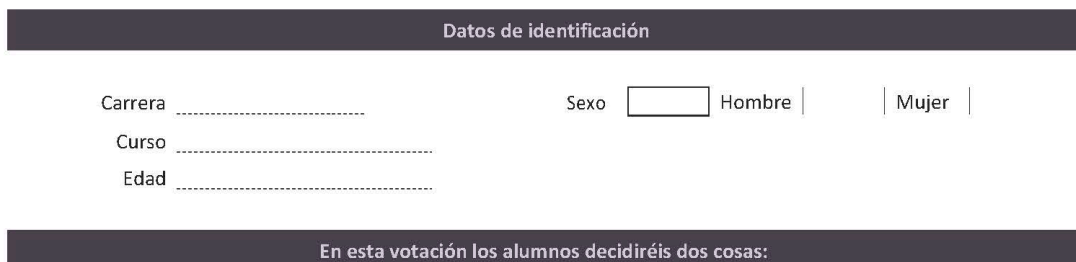

A) Los Premios TOCADOS, Gran Tocado y Joven Tocado.

- Gran Tocado, se otorga a aquella campaña/spot que os haya resultado más atractiva, la que más os haya gustado.

- Joven Tocado, se otorga a la campaña/spot en el que os hayáis visto mejor reflejados como jóvenes.

B) Los Premios a las 4 categorías publicitarias: Idea Creativa Música/Sonido, Slogan/Claim e Imagen/Realización.

Para mejor seguimiento del visionado de los spots, os facilitamos la lista donde podéis ir señalando vuestros gustos para cada premio. (HOJA DE TRABAJO)

La decisión última y definitiva la reflejaréis en el último recuadro de Votación Final. Si quisierais añadir un spot que no habéis visto en el Visionado, podéis hacerlo en el apartado "Otro*".

\begin{tabular}{|c|c|c|c|c|c|c|c|}
\hline \multicolumn{9}{|c|}{ HOJA DE TRABAJO } \\
\hline SPOT & Marca & $\begin{array}{c}\text { Gran } \\
\text { Tocado }\end{array}$ & $\begin{array}{c}\text { Joven } \\
\text { Tocado }\end{array}$ & $\begin{array}{c}\text { Idea } \\
\text { Creativa }\end{array}$ & $\begin{array}{c}\text { Música/ } \\
\text { Sonido }\end{array}$ & $\begin{array}{c}\text { Slogan/ } \\
\text { Claim }\end{array}$ & $\begin{array}{c}\text { Imagen/ } \\
\text { Realización }\end{array}$ \\
\hline & & & & & & & \\
\hline & & & & & & & \\
\hline
\end{tabular}

SPOTS QUE OPTAN POR PREMIO SOLIDARIO

\begin{tabular}{|c|c|c|}
\hline \multicolumn{3}{|c|}{ HOJA DE TRABAJO } \\
\hline SPOT & Marca & Solidario \\
\hline & & \\
\hline & & \\
\hline & & \\
\hline
\end{tabular}




\section{DISERTACIONES}

ESTUDIOS

El papel del sonido en la comunicación: contribución, funciones y efectos ISSN: 1856-9536

Doi: http://dx.doi.org/10.12804/revistas.urosario.edu.co/disertaciones/a.6537

Volumen 12, Número 2 / Julio-diciembre 2019

Versión PDF para imprimir desde

PUBLICIDAD

DECISIÓN FINAL: ANUNCIOS GANADORES ELEGIDOS

\begin{tabular}{|c|c|c|}
\hline & \multicolumn{2}{|c|}{ VOTACIÓN FINAL } \\
\hline & SPOT ELEGIDO & $\begin{array}{l}\text { JUSTIFICACIÓN DE LA ELECCIÓN: } \\
3 \text { PALABRAS / ADJETIVOS QUE } \\
\text { EXPLIQUEN TU DECISIÓN }\end{array}$ \\
\hline Gran Tocado & Otro* & $\begin{array}{l}1 \mathrm{a} \\
2^{\mathrm{a}} \\
3^{\mathrm{a}} \mathrm{a}\end{array}$ \\
\hline Joven Tocado & Otro* & 19 \\
\hline Idea Creativa & Otro* & $\begin{array}{l}1 \mathrm{a} \\
2 \mathrm{a} \\
3 \mathrm{a} \\
\end{array}$ \\
\hline Música / Sonido & Otro* & 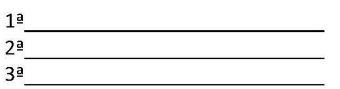 \\
\hline Slogan / Claim & Otro* & 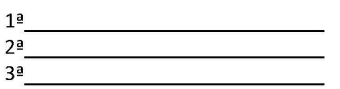 \\
\hline Imagen / Realización & Otro* & 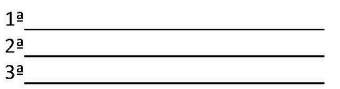 \\
\hline Solidario & Otro* & 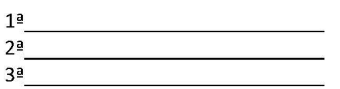 \\
\hline
\end{tabular}

Muchas gracias por su amabilidad y por el tiempo dedicado a contestar esta encuesta

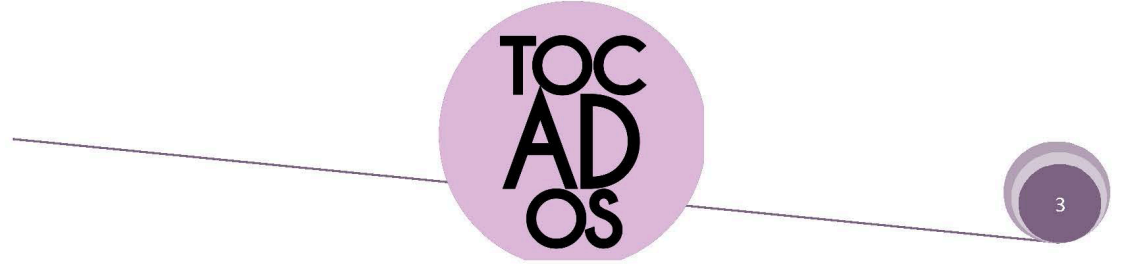




\section{DISERTACIONES}

ESTUDIOS

El papel del sonido en la comunicación: contribución, funciones y efectos ISSN: $1856-9536$

Doi: http://dx.doi.org/10.12804/revistas.urosario.edu.co/disertaciones/a.6537

Volumen 12, Número 2 / Julio-diciembre 2019

Versión PDF para imprimir desde

http://revistas.urosario.edu.co/index.php/disertaciones

Anexo 4. Cuestionario final

CUESTIONARIO FINAL. FASE CUALITATIVA TOCADOS

Y ya para finalizar, tenéis que elegir de los spots que hemos estado hablando el mejor según vuestra opinión para cada uno de los premios del festival

- Categoría Gran Tocado, se otorga a aquella campaña/spot que os haya resultado más atractiva, la que más os haya gustado

- Categoría Joven Tocado, se otorga a la campaña/spot en el que os hayáis visto mejor reflejados como jóvenes.

- Categoría Idea Creativa.

- Categoría Música/Sonido.

- Categoría Slogan

- Categoría Imagen/Realización.

- Categoría Solidario 